\title{
Article
}

\section{Technology assessment and the 'ethical matrix'}

Schroeder, Doris and Palmer, Clare

Available at http://clok.uclan.ac.uk/9696/

Schroeder, Doris ORCID: 0000-0002-3633-2758 and Palmer, Clare (2003)

Technology assessment and the 'ethical matrix'. Poiesis \& Praxis: International Journal of Technology Assessment and Ethics of Science, 1 (4). pp. 295-307. ISSN 1615-6609

It is advisable to refer to the publisher's version if you intend to cite from the work. http://dx.doi.org/10.1007/s10202-003-0027-4

For more information about UCLan's research in this area go to

http://www.uclan.ac.uk/researchgroups/ and search for < name of research Group>.

For information about Research generally at UCLan please go to http://www.uclan.ac.uk/research/

All outputs in CLoK are protected by Intellectual Property Rights law, including Copyright law. Copyright, IPR and Moral Rights for the works on this site are retained by the individual authors and/or other copyright owners. Terms and conditions for use of this material are defined in the policies page.

\section{CLoK}

Central Lancashire online Knowledge www.clok.uclan.ac.uk

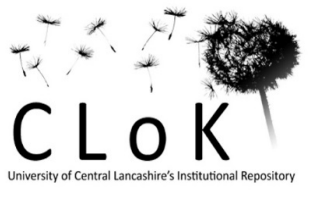




\title{
Technology assessment and the 'ethical matrix'
}

\author{
Doris Schroeder, Clare Palmer
}

Abstract This paper explores the usefulness of the 'ethical matrix', proposed by Ben Mepham, as a tool in technology assessment, specifically in food ethics. We consider what the matrix is, how it might be useful as a tool in ethical decisionmaking, and what drawbacks might be associated with it. We suggest that it is helpful for fact-finding in ethical debates relating to food ethics; but that it is much less helpful in terms of weighing the different ethical problems that it uncovers. Despite this drawback, we maintain that, with some modifications, the ethical matrix can be a useful tool in debates in food ethics. We argue that useful modifications might be to include future generations amongst the stakeholders in the matrix, and to substitute the principle of solidarity for the principle of justice.

1 Introduction

In its classical form, the goal of technology assessment is to anticipate and understand the consequences of technological and scientific innovations in order

Published online: 24 April 2003

(C) Springer-Verlag 2003

D. Schroeder $(\square)$

Centre for Professional Ethics, University of Central Lancashire, Preston, PR1 2HE, United Kingdom

E-mail: Dschroeder@uclan.ac.uk

C. Palmer

Institute for Environment, Philosophy and Public Policy, Furness College,

Lancaster University, Lancaster, LA1 4YG, United Kingdom

Parts of this paper were presented at the 2002 public meeting of the Society for Applied Philosophy, UK, as well as at a colloquium at the European Academy for the Study of the Consequences of Scientific and Technological Advances, Germany. We would like to thank participants for their comments. We are also grateful to Miltos Liakopoulos for comments on an earlier draft, and to Ruth Chadwick, Ben Mepham, and Michiel Korthals for discussions about the 'ethical matrix'. 
to determine public policies. (Gethmann and Grunewald, 1996:11) Institutions, such as the well-known but now defunct US Office of Technology Assessment, aim to provide political decision-makers with comprehensive information about new technologies so that they can, ideally, foresee potential problems. Such information has, traditionally, covered a variety of potential impacts of new technologies. More recently, ethical questions raised by particular new technologies have become significant in technology assessment. It is in this context that the 'ethical matrix', developed by Ben Mepham has emerged. This paper aims to examine the 'ethical matrix' in relation to ethical technology assessment.

\section{2}

\section{What is the 'ethical matrix'?}

How should one go about making ethical decisions in situations where different, and conflicting, interests are at stake? This is, of course, a longstanding problem in applied ethics; Mepham's ethical matrix is one development amongst many attempting to cast light on this problem, both broadly and in more particular ethical contexts. Rawls, tackling this issue in most general terms in his paper 'Outline of a decision procedure for ethics' (1951) argued that what is required, in such circumstances, are 'reasonable' or 'justifiable' principles that enable us to determine which actions would be 'just and right' (Rawls 1951:178). Such principles should, Rawls argued, be acceptable to any impartial competent judge; and they must be intuitively so, even reflecting a 'commonsense rule' (ibid. 183). Mepham's ethical matrix falls into this Rawlsian decision-making tradition; in particular, he uses what he calls 'common sense morality' as a starting point for the 'ethical matrix', and it is framed around a series of principles, which are argued to be reasonable or justifiable.

More particularly, Mepham's ethical matrix is influenced by the 'principlism approach' adopted by Beauchamp and Childress in Principles of biomedical ethics (1994). Beauchamp and Childress (1994:62) affirm 'a conception of morality that is oriented to principles and rules', where these rules are understood to be of a 'prima facie binding' nature-not absolute, but also not merely rules of thumb. In their work, Beauchamp and Childress identify four principles, which they regard as being central to biomedical ethics: respect for autonomy, non-maleficence, beneficence and justice. It is these principles on which Mepham draws to develop his ethical matrix. He keeps autonomy and justice, and rather than the separate categories of beneficence and non-maleficence introduces the category 'well-being'. This change reflects the different constituency with which food ethics, in comparison with biomedical ethics, must be concerned: animals and the environment. (Of course some issues in biomedical ethics raise questions about animals-in particular animal experimentation-but animals are not so central in biomedical ethics, as a whole, as they are in food ethics). So, Mepham's ethical matrix has the following form: an $\mathrm{x}$-axis listing the principles modified from Beauchamp and Childress and a $y$-axis expanding the moral realm as appropriate for food ethics.

It is suggested that the matrix's principles are taken from several major (Western) ethical theories, namely consequentialism (well-being), deontology (autonomy) and Rawlsian contract theory (justice) ${ }^{1}$. Of course, using a mixture of different ethical theories does not supply a new theory. But that is not the

\footnotetext{
${ }^{1}$ Virtue ethics, an approach which has seen a revival over the past decades has not been included explicitly, although one could argue that 'justice' being one of the cardinal virtues also represents virtue ethics.
} 
intention. Mepham (2000:167) specifically emphasises that 'the framework is not an ethical theory'. It is, rather, a set of moral premises that is broad enough to align with common sense morality and is intended to clarify and assist discussion about ethical problems and dilemmas. A basic version of Mepham's ethical matrix looks as follows:

\begin{tabular}{|c|c|c|c|}
\hline & Well-being & Autonomy & Justice \\
\hline Citizens & $\begin{array}{l}\text { Food safety and acceptability; } \\
\text { quality of life }\end{array}$ & $\begin{array}{l}\text { Democratic, } \\
\text { informed choice }\end{array}$ & $\begin{array}{l}\text { Availability of } \\
\text { affordable food }\end{array}$ \\
\hline Industry & $\begin{array}{l}\text { Satisfactory income and } \\
\text { working conditions }\end{array}$ & $\begin{array}{l}\text { Appropriate } \\
\text { freedom of action }\end{array}$ & $\begin{array}{l}\text { Fair trade laws } \\
\text { and practices }\end{array}$ \\
\hline Animals & Animal welfare & Behavioural freedom & Intrinsic value \\
\hline Environment & Conservation & Biodiversity & Sustainability \\
\hline
\end{tabular}

This article will examine the matrix critically, but criticism will be confined in two different ways. First, we will not criticise the classical tradition of technology assessment of which the ethical matrix is an example. It can, for instance, be argued that classical technology assessment is too reactive. It is too late to assess the potential consequences of a new technology when it has already been developed. Instead constructive, democratic technology assessment (also known as CTA) should be part of the development process (Boxsel, 1991). Indeed, many working within the philosophy of technology argue that modern technology is always already value-laden (often in ways reflecting human domination of other humans or the natural world); ethical assessment after technology development only serves to legitimate oppressive technological development. Debates of this nature have been documented elsewhere and hence it seems unnecessary to repeat them here ${ }^{2}$. Second, we will also not repeat criticism Beauchamp and Childress received for principlism (such as that they manifest Western cultural bias). Although this criticism would apply to the ethical matrix by default, we shall confine ourselves to criticism that is especially relevant to the ethical matrix as such. These criticisms would rule out the whole ethical matrix project-whereas we will argue that despite some significant difficulties, a reformed version of the ethical matrix could be a useful tool in technology assessment.

\section{3}

\section{Assessing the ethical matrix}

There are at least two main ways to assess a tool's usefulness. First, if one knows exactly for which purpose and to which effect the creator of a tool says it is to be used, one can test its usefulness by establishing whether it, indeed, does what the inventor claims. The most straightforward way to test the matrix's usefulness, according to this approach, is to compare the aims set by its inventor with its performance. According to its inventor, the ethical matrix aims to provide 'a framework for rational ethical analysis' in the area of modern biotechnologies (Mepham, 2000:165) and 'seeks to encourage rational decision-making'. (Food Ethics Council, 2001:7). To assist in enabling rational decision-making by ethical analysis sounds very much in line with the aims of technology assessment. If the ethical matrix could achieve this, it would certainly be a useful tool in technology assessment.

\footnotetext{
${ }^{2}$ For an extensive bibliography of debates on technology assessment, see Gethmann and Grunwald (1996).
} 
On the other hand, it is possible that one does not know the scope of the functions of a tool. In that case, one can test it for various purposes that seem broadly appropriate and define its functions-what it is successful at doing-retrospectively. (Alexander Fleming, for instance, defined the use of penicillin retrospectively). As a second way to assess a tool's usefulness, this approach requires a number of trial and error experiments. In the context of the ethical matrix, then, one can consider the experiences of those who have already used it in technology assessment. Have they found it to be useful?

Those who used the ethical matrix in public participation exercises concluded that:

1. It identifies issues and focuses debate

2. It is a very good vehicle for education and discussion

3. It teases out issues and people's feelings

4. It enables a wide range of issues to be discussed

5. It aids the decision-making process (ibid.) ${ }^{3}$.

At first sight, then, the ethical matrix does seem to have promise as a tool for technology assessment. However, we want to explore the nature of the matrix more closely, in order to consider just how useful a tool it might be.

\section{4}

\section{Aims of the ethical matrix}

As noted above, the main aim of the matrix is to facilitate rational ethical analysis and decision-making. Although Mepham refers almost exclusively to Rawls and Beauchamp/Childress as background theory, the terms 'rational' and 'analysis' as well as the matrix structure suggest that his approach belongs to the field of 'best reasons morality'. 'Best reasons morality' tries to arrive at moral decisions by searching for the best, most rational reasons to support any course of action. The seminal work in this field is The moral point of view (1965) by Kurt Baier, and the idea has been supported more recently by James Rachels (1993) in Elements of moral philosophy. According to Baier (1965:28-50), moral reasoning involves three steps. First, finding and surveying the facts 'with a view to determining which of them are relevant' (ibid. 28). Second, weighing the facts, i.e. establishing the 'relative' weight of these considerations with a view to deciding which course of action has the full weight of reason behind it (ibid.) Third, making a rational decision based on the former two. Moral principles are used to aid step two (weighing the facts) and step three is inevitable once all the facts are present in a weighed form.

Following Baier, we shall assume that finding and weighing the facts is possible in moral decision-making and can lead to rational decisions. (Again, this is not the place to criticise 'best reasons morality'. Likewise, we are going to lay aside problems about the naturalistic fallacy in this context). Given its stated aim, does the ethical matrix help with these two essential steps necessary for rational decision-making?

\footnotetext{
${ }^{3}$ These five comments were not chosen randomly by us but selected by Ben Mepham as 'Comments on the matrix' (Mepham, 2001:7). For the remainder of the article, we shall disregard the comment that the matrix is useful for education purposes, as we are interested in classical technology assessment, which is not directly related to education. All comments relate to the use of the ethical matrix in public participation exercises. Although one of us (DS) was involved in an expert committee that used the matrix, not enough comments from other expert committees were available to include this form of technology assessment.
} 


\section{Finding the facts}

When talking about 'finding the facts' (and we suspect this is also meant by Baier and Mepham), we do not mean any metaphysical truth. We simply mean empirical facts relevant to moral dilemmas (although these may, of course, be contested). A number of examples:

- According to the World Health Organisation (2002), 2.1 million people, mostly children, die every year from diarrhoeal diseases. Hygiene interventions would reduce diarrhoea related mortality by $65 \%$.

- Bovine somatotrophin (BST), a genetically-engineered protein hormone, used in cows, increases milk yield by up to $15 \%$. At the same time BST increases the risk of clinical mastitis ${ }^{4}$ by at least $15-45 \%$ (European Commission, 1999) ${ }^{5}$.

- $10-35 \%$ of heavy drinkers develop alcoholic hepatitis with a further $10-20 \%$ of this group developing alcoholic liver cirrhosis (UCDavis Health Systems, 2000 ). In the UK, in 2001, 23\% of patients on the waiting list for liver transplants could not be treated because of organ shortages (UK Transplant 2002).

Does the 'ethical matrix' help to find facts of this type? To answer this question, it is important to realise that one of the most important issues in fact-finding with regard to moral dilemmas is asking an appropriately wide range of questions, i.e. looking as far as possible for all the relevant facts. For instance, in the case of bovine somatotrophin, a European Commission (1999) report came to the conclusion that 'animal welfare does not appear to have been an issue in the decisionmaking process on BST in the USA'. However, animal welfare is a morally relevant fact, unless one subscribes to the view that animals are insentient, or that they lack interests. To ask the question which effect-other than increased yield-BST will have on dairy cows, is hence an important one. No matter how good the various experts are in supplying facts for consideration, if half of the questions are missing, the resulting decision will not be as unbiased and pertinent as it could be.

In this area, the ethical matrix is very useful for two reasons, related to the two axes. The mere existence of the $y$-axis invites debates about stakeholders. Who will be affected, directly or indirectly, by the introduction of a particular technology? Groups and entities that might otherwise be forgotten (such as the US dairy cows) are likely to emerge if the matrix is being used, since animals and the environment are default entries in the matrix. It may, then, help in identifying relevant facts for a wider range of stakeholders along the $\mathrm{x}$-axis than would otherwise be the case.

The y-axis of the matrix may also help in the identification of new issues. Supposing a straightforward consequentialist were to ethically assess turkey farming in the United Kingdom. Asking only questions about welfare or beneficience/non-maleficience might not uncover potential problems of a different nature. For instance, according to the then Ministry for Agriculture, Fisheries and Food (MAFF: 1995), selective breeding of turkeys makes it nearly impossible for them to mate naturally. Hence, artificial insemination is a near-universal feature of turkey breeding. It is certainly conceivable that a consequentialist would not object to this practice on welfare grounds, and thus not consider this to be a

\footnotetext{
${ }^{4}$ Painful inflammation of the udder.

${ }^{5}$ Bovine somatotrophin is being used widely in dairy cattle in the United States, but its use is prohibited within the European Union.
} 
relevant 'fact'. But from other perspectives, ethical problems are raised here. Someone who considered 'naturalness' in animal lives, or animals' 'bodily integrity' to be important would, most definitely, object. But in incorporating principles drawn from different approaches in ethics (utilitarianism, deontology, and Rawlsian contract theory), the kinds of concerns located are not restricted to those of (say) the consequentialist (at first sight, at least). Equally, a fact, and hence a question, that is essential to a consequentialist might be irrelevant to a Kantian (e.g. how many people suffer as a consequence of an agent's honesty). By including a principle from several major ethical theories, the probability of uncovering all relevant questions is increased significantly.

Hence, the structure of the ethical matrix supports the fact-finding mission of 'best reasons morality' in so far as it facilitates the raising of questions from a variety of angles. Of course, answers to these questions are essential in order to proceed to decision-making.

6

\section{Weighing the facts}

The second step in 'best reasons morality' is weighing the facts with principles. This fits rather neatly with the ethical matrix since it already provides three principles: respect for well-being, autonomy, and justice. Given that we are aiming for rational decisions in both best reasons morality and the ethical matrix, the emphasis during this process (weighing the facts) is on justification (Baier, 1965:42, 46). Rational decisions can be explained and justified to others (Gosepath, 1999:10, 45). Let us look at the example of bovine somatotrophin again.

In the first step of using the matrix, we have already compiled a list of questions and answers as part of a fact-finding mission. Some of the facts in the debate on BST could be the following:

1. Dairy cattle treated with BST suffer from various ailments

2. Ethically indifferent producers and users benefit financially from BST

3. Ethically concerned producers are economically harmed

4. Ethically concerned producers are potentially coerced

Points 1-3 are relevant to the principle of well-being, with 1 and 3 expressing harms and 2 expressing a benefit. Position 4 refers to the principle of autonomy and expresses a violation. How could our facts be weighed against each other? The ethical matrix does not give an answer to this rather essential question ${ }^{6}$. This means that it does not provide the stepping stone from facts to decisions. Could there be such a stepping stone? Three possibilities suggest themselves.

\section{1}

\section{Counting the positive and negative outcomes}

In our BST example, we recorded three violations and one instance of support for a principle. On a strict quantitative counting, the technology should be rejected. However, this is extremely simplistic as it does not take severity of violation or

\footnotetext{
${ }^{6}$ Baier (1965:150-162) gives a partial answer in that he argues for the superiority of moral reasons over considerations of self-interest. Increased farming profits following the introduction of BST would only outweigh animal suffering if animals were excluded from the moral sphere. If animal suffering counted as a morally relevant fact, BST could not be rationally justified according to Baier's 'best reasons morality'.
} 
extent of respect into perspective. Two minor instances of respect could enable a decision that allows one major violation. Hence, the problem remains the same. How are the answers in individual cells weighed to ensure that significant violations/respect for principles are recognised and distinguished from minor violations or instances of respect? More fundamentally, this approach would contradict the underlying vision of the matrix, which purposefully allows a number of major philosophical traditions to supply principles. If the answers to individual cells were provided using all traditions, but the final decision made by maximising quantification, the consequentialist approach would rule supreme (we alluded to this earlier). For a deontologist this maximisation would be unacceptable. On a level playing field between different traditions, this possibility must, hence, be excluded.

\section{2 \\ Building a hierarchy of principles}

One could produce a hierarchical list of cells for the weighing. For instance, harm to human autonomy is more serious than harm to human well-being. Harm to human well-being is more serious than harm to animal welfare. Harm to animal welfare is more serious than harm to animal autonomy etc ${ }^{7}$. There is an obvious problem with this approach (except for the impossibility of ever agreeing on such a hierarchy). One reverses the decision taken at the outset that the matrix should leave room for several philosophical traditions on two accounts. If one believes that the prioritising of autonomy over well-being is the essence of deontology, one prioritises the latter over consequentialism. If one believes that the maximisation strategy is the essence of consequentialism rather than the maximisation of a specific principle (e.g. well-being), one prioritises again, this time consequentialism over any other approach. In both cases, the founding idea of the matrix that there should be room for diverging philosophical traditions has been breached.

\section{3}

\section{Stakeholder discourse and majority vote (based on full information)}

Instead of looking for a solution in the matrix for the weighing process, one could use the matrix as an information-seeking tool and decouple the weighing. As previously noted, the matrix is an excellent tool for fact-finding and recording. On the basis of these facts, one can then move forward to a weighed decision by stakeholder discourse and-if necessary-majority voting. We shall not go into detail here about the conditions for informed, uncoerced, participative discourse $^{8}$, but do believe that this is the only workable option to move forward with the matrix. To conclude this section, the ethical matrix is not a tool for weighing facts and hence its application does not-automatically-provide decisions. Finding all the relevant facts and weighing them are two distinct activities, as

\footnotetext{
${ }^{7}$ This, to some extent, resembles the approach taken by Donald Van De Veer in 'Interspecific justice' (1979).

${ }^{8}$ For a good comment on deliberative democracy, see Robert Goodin 'Democratic deliberation within' (2000). Clearly, difficulties arise in this analysis both with respect to what constitutes stakeholders - can the environment be thought of as a stakeholder?-and also concerning how to deal with those one might definitely want to include as stakeholders (e.g. animals and children) but who are unable to enter deliberative discourse themselves. These issues obviously require further investigation.
} 
Baier rightly pointed out, and the matrix is only helpful with the first step. However, this does not mean that the matrix is deficient or useless. On the contrary, bringing as many ethically relevant facts into the open as possible is an essential and very valuable activity, which forms the foundation of the next step, deliberative informed discourse.

Looking back at the original starting point; in what sense is the ethical matrix useful? Commentators of the matrix have said the following, as noted above. (1) It identifies issues and focuses debate. (2) It is a very good vehicle for discussion. (3) It teases out issues and people's feelings. (4) It enables a wide range of issues to be discussed. (5) It aids the decision-making process. Clearly, these comments focus on the fact-finding element of the matrix and this makes sense, as we have suggested. But what about point 5 in relation to Mepham's own aims? As noted earlier, Mepham wants to provide 'a framework for rational ethical analysis' in the area of modern biotechnologies, specifically food ethics, which 'seeks to encourage rational decision-making'. Fact-finding, in the sense described, is the foundation of rational decision-making. Hence, the matrix does go some way towards achieving this aim: it helps to meet necessary fact-finding conditions, whilst not in itself being sufficient for rational decision-making-because it does not provide a mechanism to balance the different ethical concerns which such fact-finding raises. Agreement, thus, still needs to be achieved in some form of deliberative discourse.

In the last section of this article, we shall ask: Given that the matrix is useful in principle, could it be improved in detail?

\section{7}

\section{Improving the ethical matrix?}

Looking at the matrix, two types of changes seem plausible: changes to the structure and changes to the content. The structure consists of stakeholders on the $\mathrm{y}$-axis, principles on the $\mathrm{x}$-axis and questions and answers in their intersections. This is an excellent structure, in our opinion. It forces those who use the matrix to look at implications for all stakeholders from a variety of different perspectives. Hence, we would not suggest any changes.

Changes to the content could take two different forms. First, the x- and/or the $y$-axis could be made flexible in terms of content, i.e. those who use the matrix could decide which principles and which stakeholders they want to include on every single occasion. Second, the $\mathrm{x}$ - and/or the $\mathrm{y}$-axis could remain determined, but with different content, i.e. different default stakeholders and different default principles.

Matthias Kaiser and Ellen-Marie Forsberg (2001) used the matrix in the first sense when assessing a special tax for the use of common resources by Norwegian fisheries. They took an empty matrix shell and filled it with their own stakeholders and principles. As a result, animals (fish) were not included as stakeholders, whilst the principle of autonomy was replaced by the principle of dignity. Without commenting on this particular case, the question is: Would it be an improvement of the ethical matrix as a tool to understand it as a shell, to be given content by its users? We believe not. The matrix's strength lies in its capacity to enable comprehensive fact-finding. One way to subvert this approach is by-consciously or unconsciously-forgetting stakeholders and principles. To add content to the matrix must not be seen as overly restrictive, but rather as ensuring that all stakeholders receive consideration. To include animals and the environment by default is a sensible move, in our opinion, because they can-in 
principle-have no direct representatives. Let us therefore, discard the idea of making the 'ethical matrix' wholly flexible and undetermined in terms of content. But what about the content given? Are the default stakeholders (citizens, industry, animals and environment) and the default principles (well-being, autonomy, justice) satisfactory?

\section{1}

\section{Default stakeholders}

Why include certain stakeholders and not others by default? The principal reason for including default stakeholders must be because they could be overlooked if technology assessment was not undertaken very carefully. What characterises these types of stakeholders? Obviously, that they can - in principle-not represent themselves. As was previously noted, this is the case with animals and the environment.

But is this list exhaustive? No. At least one further stakeholder suggests itself in this context, namely future generations. They also do not-in principle-have the ability to represent themselves but their interests will be affected-and, indeed, effected-by the consequences of our actions. Hence, they are legitimate stakeholders ${ }^{9}$.

We agree that simplicity is a virtue when setting-up matrices ${ }^{10}$, where each addition on one axis will multiply the number of cells to be filled in. However, we believe that future generations ought to be included as a default stakeholder. Then, it can be argued that those who have a place by default are all major groups who can-in principle-not intervene in the decision-making process.

\section{2}

\section{Default principles}

The principles included in the 'ethical matrix' are: well-being, autonomy, and justice. Is this a complete list? Completeness of ethical principles can, of course, never be the aim for the $\mathrm{x}$-axis of the ethical matrix. Even if a complete list of ethical principles existed somewhere, it could never be checked against all stakeholders in any meaningful and time-efficient way. Hence, it is necessary to select-and a selection runs the high risk of being biased. In the Western context, how could one arrive at a very short, reasonably balanced list of principles? Perhaps by asking moral philosophers on a grand scale two questions. First, what are the top three normative ethical theories? Second, which principle best represents each of these theories ${ }^{11}$ ?

\footnotetext{
${ }^{9}$ Although it has been argued that future persons 'have no rights against present persons nor, therefore, any rights that present persons save or conserve anything for them' (Steiner, 2002:295), this does not mean that future persons' interests should not be taken into consideration. It simply means that nothing as strong as rights can be ascribed to them, as rights-according to Steiner-necessitate correlativity, which, in principle is not given between present and future persons. (The same lack of correlativity applies to the relationship between humans on the one hand and animals and the environment on the other hand).

${ }^{10}$ Ben Mepham suggested this to one of us as the reason for limiting principles.

${ }^{11}$ This, of course, poses a difficulty for those who believe that an ethical theory is about a method rather than principles. For instance, if one believed that consequentialism is essentially about maximising of a chosen principle rather than the principle itself, one is already at a loss as to what should be included in the matrix.
} 
Alternatively, one could look at text books on moral philosophy and see which theories are discussed most often. Even without a survey and without a comprehensive list of text books, it is possible to predict the top two: consequentialism and deontology. But what would make it into third place? Virtue ethics or contractualism, or feminist ethics? (Of course, looking at textbooks does not reveal any abstract truth about the importance of various moral theories or principles. It just reveals academics' preferences for them). The question here is: Which type of matrix would best achieve the aims of finding facts and supporting deliberative discourse? And one thing is interesting when looking at textbooks. Of the main texts, both Sterba (1998) and LaFollette (2000) subsume contractualism into deontology, whilst only Singer (1991) and Benn (1998) list contractualism as a separate tradition and theory (all four list virtue theory separately). On this count (which does not claim to be representative), virtue ethics should provide the third principle as contractualism is covered, according to some, by deontology.

The fact that contractualism is often grouped with deontology and that virtue ethics is an important separate approach not represented in the matrix leads to two interesting developments that simultaneously resolve problems we have with individual cells of the matrix. As Kaiser and Forsberg suggest (2001:197), we would anticipate problems with the principle of 'justice', mainly due to tensions between an egalitarian and a meritorious understanding of distributive justice. To illustrate this tension, one only needs to compare Rawls' conception of justice in A theory of justice (1999) with the later conception in The law of peoples (1999a) ${ }^{12}$. In the former, Rawls (1999:65f) argues for a strongly egalitarian distribution of resources unless a non-egalitarian distribution makes both parties involved better off. In the latter, Rawls (1999a: 8f) does not insist at all on an egalitarian distribution and rather argues that a just distribution takes merit into account. For instance, those who do not care properly for their own land and do not control birth rates have no claim from justice for an egalitarian distribution.

In the matrix, the intersection of 'justice' and 'citizens' contains the specification: 'Availability of affordable food'. Here the tension between an egalitarian and a meritorious understanding of distributive justice could become problematic. Following the later Rawls, it is not a matter of justice to provide affordable food on an egalitarian basis to those who-due to their own lack of effort, for instance-do not do so themselves.

How does this potential problem relate to the point made earlier (contractualism can be understood within deontology, and no principle from virtue ethics - an important ethical theory-is present in the matrix)? One could argue that 'justice' is not an essential principle, if one wanted to restrict principles to three, given its contentious and ambiguous nature. In any case, it is almost always possible to derive demands for justice from demands for autonomy (which could explain why Sterba and LaFollette subsume contractualism under deontology). For instance, the availability of affordable food could be derived as follows (adapted from Gewirth, 1984): Food is a necessary condition of action in general. Action as such is the independent variable of all morality (act to maximise happiness, act as if the maxim of your action were to become a

${ }^{12}$ A theory of justice deals with questions of national distributive justice, whilst The law of peoples deals with international distributive justice. However, the tensions described do not simply arise because of the different contexts, they could just as well arise within the national sphere only. 
universal law, act as God commands etc.). What applies to action in general also applies to autonomous action (autonomous action is a sub-set of action). Every agent must accept that his or her prudential right-claim ('I must have freedom and well-being, which includes access to food') becomes a moral right and therefore an obligation when realising that all humans are actual or prospective agents. Hence, respect for autonomy involves respect for the preconditions of autonomy, which include well-being (food) and freedom. This way, one derives the demand that was listed under 'justice' indirectly from the demand to respect autonomy.

Likewise, fair trade laws and practices (intersection of 'justice' and 'industry') could be constructed as a precondition for autonomous action by industry. Therefore, it is possible to remove 'justice' from the $\mathrm{x}$-axis to make room for another principle. And, given that virtue ethics is not represented in the matrix, the new principle could be an important virtue. The ancient Greek cardinal virtues, justice, courage, wisdom and temperance (Plato, 1993:147-156) are not suitable, though. Courage, wisdom and temperance are hopefully with those who use the ethical matrix, but it does not make sense to ask: What would respect for courage imply for animals? Or, what would respect for wisdom imply for industry? and we have already explained the drawbacks of using 'justice' as one of the matrix's principles.

Without going through all the Aristotelian virtues from expansive hospitality to easy grace, one virtue-generosity and its 'sister virtue' solidarity ${ }^{13}$ - seems most suited to the ethical matrix. The virtue of 'human solidarity' can be defined as 'something within each of us-our essential humanity-which resonates to the presence of this same thing in other human beings' (Rorty, 1989:189).

However, it could be argued that solidarity generates difficulties as a moral demand to be included in the matrix, as solidarity is often understood contrastively. It relies on a potentially problematic 'one of us' feeling (solidarity, yes, but only with fellow academics, fellow Europeans, fellow whites, not fellow humans) (ibid. 190f). And even worse, how can one interpret solidarity for the non-human stakeholders, animals and the environment? We would like to follow Richard Rorty (ibid. 192) in this respect. Rather than claiming that solidarity is a universal virtue of humankind, which can sometimes be lost, we would see it as an aim in moral life to extend a sense of 'we' to people and even non-people, whom were previously thought of as 'they'. Such an approach fosters moral inclusiveness, but-in response to concerns of feminist ethicists-need not eliminate awareness of potentially important moral differences between different stakeholders, human and non-human ${ }^{14}$.

\footnotetext{
${ }^{13}$ Solidarity is not included amongst Aristotle's list of virtues in the Nicomachean ethics, but it can be understood as a 'sister virtue' of generosity, for two reasons. First solidarity requires sacrifice for the benefit of others, i.e. giving to others, as does generosity. Hence, both fall under the genus 'benevolence'. Second, although it might appear that solidarity requires a broader set of beneficiaries - in its universal form even humankind-one would not normally call a person generous if s/he was generous in a very selective way. Hence, both virtues involve giving to others without prejudice and selectivity. The only difference between the two is that solidarity comes with a pre-determined reason for generosity, namely fellow feeling, whereas generosity as such can be undertaken from a variety of motives (e.g. a belief in egalitarianism, a wish to create happiness for others).

${ }^{14}$ See, for instance, Val Plumwood's argument for the importance of solidarity in 'Deep ecology, deep pockets and deep problems: a feminist ecosocialist analysis' (2000).
} 
Perhaps a good way to start this new 'we'-virtue of solidarity is by including it in the ethical matrix in place of justice. It would remain to be seen in future public participation and/or expert committee assessments whether it is a useful alteration, or whether ethical technology assessment is better served with the principles currently used. One thing can be said before any trials and experiments. To include solidarity instead of justice could shift the focus of the matrix from considerations of rights to considerations of obligations. Justice tells us which rights stakeholders have, what they deserve, what is their just due. Solidarity changes the perspective and asks about duties and obligations to others ${ }^{15}$. We believe that this shift of emphasis could be most fruitful, as fantasising about rights without thinking about counterpart obligations can be regarded as irresponsible (O'Neill, 2002:18). Solidarity-as something in us that 'resonates' with others-also provides the possibility of a place for moral emotion in the ethical matrix, without thereby undermining the significance of rationality in moral decision-making.

\section{8}

\section{Conclusion}

The ethical matrix is an excellent fact-finding tool to support ethical technology assessment. Due to the inclusion of default stakeholders whose interests must be considered, narrow and biased approaches can be challenged. In addition, the presence of several principles and philosophical traditions opens further opportunities for balanced fact-finding. However, rational decision-making, as rational technology assessment, requires more than the discovery and survey of relevant facts. Facts also need to be weighed and accorded importance or insignificance. In this respect, the matrix is unhelpful as it does not provide a mechanism to balance different ethical concerns. Accepting this drawback, we outlined two modifications to the structure of the matrix: the inclusion of future generations amongst stakeholders and the replacement of the principle of justice with the principle of solidarity. The former completed the set of main stakeholders who cannot represent themselves. The latter added an element of obligations rather than rights to the matrix and introduced virtue theory amongst the principles.

It remains to be noted that the ethical matrix is not an ethical theory. Its usefulness cannot be proven deductively or analytically. It is necessary to stop, think and analyse its advantages and disadvantages. We would therefore hope that continued use of the matrix in public participation exercises and expert committees will fuel further debates and potentially lead to further refinements.

\footnotetext{
${ }^{15}$ An example will clarify this point. A person (A) is presented with two men, one highly malnourished $(\mathrm{X})$, one in the possession of reasonable supplies of food $(\mathrm{Y})$. Alas, $\mathrm{Y}$ refuses to give any food to $\mathrm{X}$. Judging this situation without any further information, A can reasonably come to the conclusion that $\mathrm{Y}$ is not blessed with the virtue of solidarity (assuming that the food is not needed for others who are malnourished or starving). On the other hand, A cannot yet proclaim on whether $\mathrm{Y}$ is just or not. It is possible that there are just reasons for Y's refusal to share food with X. Since Aristotle, justice requires identical cases to be treated identically. If, for instance, $X$ has in the past-due to sheer laziness - stolen food from $\mathrm{Y}$ leaving $\mathrm{Y}$ malnourished, $\mathrm{Y}$ can justly refuse to give food to $\mathrm{X}$. In that case, $\mathrm{X}$ has no right to food from the point of view of justice. However, from the point of view of solidarity, Y might still—-despite X's past deeds-feel the obligation to share food with him.
} 


\section{References}

Baier K (1965) The moral point of view-a rational basis for ethics. Random House, New York

Beauchamp T, Childress J (1994) Principles of biomedical ethics, 4th edn. Oxford University Press, New York

Benn P (1998) Ethics. UCL, London

Boxsel JAM (1991) Konstruktive Technikfolgenabschätzung in den Niederlanden. In: Kornwachs K (ed) Reichweite und Potential der Technikfolgenabschätzung. Stuttgart, pp 137-154

European Commission (1999) Consumer policy and health protection directorate: Report on animal welfare aspects of the use of bovine somatrophin. Bruxelles

Food Ethics Council (2001) After FMD: aiming for a values-driven agriculture, Food Ethics Council Report IV. http://wwwfoodethicscouncilorg

Gethmann CF, Grunwald A (1996) Technikfolgenabschätzung: Konzeptionen im Überblick. In: Graue Reihe, Europäische Akademie zur Erforschung von Folgen wissenschaftlichtechnischer Entwicklungen, no 1

Gewirth A (1984) The justificatory argument for human rights. Social Philosophy \& Policy $1(2): 1-24$

Goodin R (2000) Democratic deliberation within. Philosophy and Public Affairs 20: 81-109

Gosepath S (1999) Praktische Rationalität-Eine Problemübersicht. In: Gosepath S (ed) Motive, Gründe, Zwecke-Theorien praktischer Rationalität. Fischer Taschenbuch Verlag, Frankfurt

Kaiser M, Forsberg E-M (2001) Assessing fisheries-using an ethical matrix in a participatory process. J Agric Environ Ethics 14: 191-200

LaFollette H (ed) (2000) Ethical theory. Blackwell, Oxford

MAFF (1995) Report of the committee to consider the ethical implications of emerging technologies in the breeding of farm animals. HMSO, London

Mepham B (2000) A framework for the ethical analysis of novel foods: the ethical matrix. J Agric Environ Ethics 12: 165-176

Mepham B (2001) Comments on the matrix

O'Neill O (2002) A question of trust. Cambridge University Press, Cambridge

Plato (1993) Der Staat. Felix Meiner Verlag, Hamburg

Plumwood V (2000) Deep ecology, deep pockets and deep problems: a feminist ecosocialist analysis. In: Light, Katz, Rothenberg (eds) Beneath the surface: critical essays in the philosophy of deep ecology. Cambridge MIT Press, pp 59-84

Rachels J (1993) Elements of moral philosophy

Rawls J (1951) Outline of a decision procedure for ethics. The Philosophical Review 60: 177-197

Rawls J (1999) A theory of justice, rev edn. Oxford University Press, Oxford

Rawls J (1999a) The law of peoples. Harvard University Press, Cambridge Massachusetts

Rorty R (1989) Contingency, irony, and solidarity. Cambridge University Press, Cambridge

Singer P (ed) (1991) A companion to ethics. Blackwell, Oxford

Sterba J (ed) (1998) Ethics: the big questions. Blackwell, Oxford

Steiner H (2002) Persons and times. In: Chadwick R, Schroeder D (eds) Applied ethics, vol VI. pp 286-297

UCDavis Health Systems (2000) Cirrhosis. http://wellnessucdavisedu/medical_conditions_az/cirrhosis75html

UK Transplant (2002) Activity summary for 2001. http://wwwuktransplantorguk/statistics/ general_statistics/activity_summary_2001htm

Van De Veer D (1979) Interspecific justice. Inquiry 22: 55-79

World Health Organisation (2002) Water and sanitation. http://wwwwhoint/water_sanitation_health/General/factsandfigureshtm 